\title{
Biodiversity and seasonal variations of zooneuston in the northwestern Mediterranean Sea
}

\author{
France Collard ${ }^{1,2, *}$, Amandine Collignon ${ }^{1,3}$, Jean-Henri Hecq ${ }^{1,3}$, \\ Loïc Michel ${ }^{1}$ \& Anne Goffart ${ }^{1,3}$
}

\footnotetext{
Laboratory of Oceanology, MARE Centre, University of Liège, B6C, 4000 Liège, Sart Tilman, Belgium.

Laboratory of Functional and Evolutionary Morphology, AFFISH-RC, University of Liège, B6C, 4000 Liège, Belgium.

3 Station de Recherches Sous-Marines et Océanographiques (STARESO), BP 33, 20260 Calvi, France.

* Corresponding author: france.collard@ulg.ac.be
}

\begin{abstract}
Neuston includes animals and plants inhabiting the surface layer of the water column. The neustonic area is an accumulation zone for bacteria, organic molecules but also terrestrial debris. The surface layer is also the air/water exchange region. Therefore, neustonic organisms are directly exposed to several constraints such as wind stress and turbulence. The present study aims to characterize the zooneuston in terms of abundance and biodiversity and to evaluate the impacts of wind stress on neustonic abundance. Zooneustonic and zooplanktonic (depth of 5 meters) samples were collected twice a month between 30th August 2011 and 10th July 2012 in Calvi Bay, Corsica. Zooneustonic biodiversity was high and, notably, twenty-eight copepod genera were identified. Among these copepods, several organisms, belonging to the Pontellidae family, were much more frequent in neuston than in underlying plankton and their abundance depended on wind direction. Taxon-specific trends in seasonal abundance variation were present. For example, individuals of the Acantharia Lithoptera spp. were found in summer whereas the Pontellidae Anomalocera patersoni appeared in winter. Overall, our data provide a first step towards a better knowledge of neuston community structure in the Mediterranean Sea.
\end{abstract}

KEY WORDS: Neuston, Pontellidae, Mediterranean Sea, Plankton, Wind forcing.

\section{INTRODUCTION}

The neuston comprises organisms inhabiting the surface layer of the water column, whereas planktonic organisms inhabit the subsurface layer (NAUMANN, 1917). Neustonic organisms live under a particular, not well-structured surface microlayer (SML), composed of colloids and macromolecules coming from dissolved organic matter and bacteria (SIEBURTH, 1983). The surface layer is a critical zone for marine species, and is notably a feeding area for fish (CARDINALE et al., 2003; PUSINERI et al., 2005). The surface layer is also an accumulation zone of pollutants (GARCIA-FLOR et al., 2008) and debris such as terrestrial debris or (micro)plastics (RYAN et al., 2009) that can threaten marine organisms (LAIST, 1997; MATO et al., 2001; GREGORY,
2009; Collignon et al., 2012 \& 2014). Due to its intermediate position between the atmosphere and the water column, the neuston is exposed to many constraints related to atmospheric conditions: high light intensity, wind stress, turbulence and temperature variations. Both physical and chemical parameters of seawater can affect zooneuston, and sea surface temperature and salinity notably influence the distribution of Pontellidae copepods (ZAITSEV, 1971). Copepods are known to migrate vertically according to light (HANEY, 1988), water density (HARADA et al., 1985), oxygen concentration (HERMAN, 1984), or phytoplankton abundance (and therefore nutrient concentration, TISELIUS, 1992). In the Black Sea, neustonic communities resemble the underlying plankton (ZAITSEV, 1971). However, some neustonic species display particular morphological or ecophysiological adaptations. 
For example, neustonic bacteria communities are different from planktonic communities (FRANKLIN et al., 2005) and phytoneuston differs from phytoplankton (HARDY \& APTS, 1984; LYALYUK \& LIPNITSKAYA, 2003). ZAITSEV (1971) also reported that Pontellidae copepods are characteristic of the neuston. Very few studies deal with neuston in the Mediterranean sea (OLIVAR \& SABATES, 1997). The diversity and abundance of mediterranean zooneustonic organisms, as well as seasonal and daily variations of these organisms remain unknown to date. In this context, aims of this study were (1) to assess zooneuston diversity in a wellpreserved Mediterranean area, (2) to quantify the abundance of dominant organisms at each season, and (3) to examine relations between neuston abundance and environmental parameters. To achieve this goal, neuston community structure in Calvi Bay (NW Corsica, France) was analyzed over a 10-month-long sampling period.

\section{MATERIAL AND METHODS}

\section{Sample collection}

Zooneuston and zooplankton samples were collected twice a month between 30th August

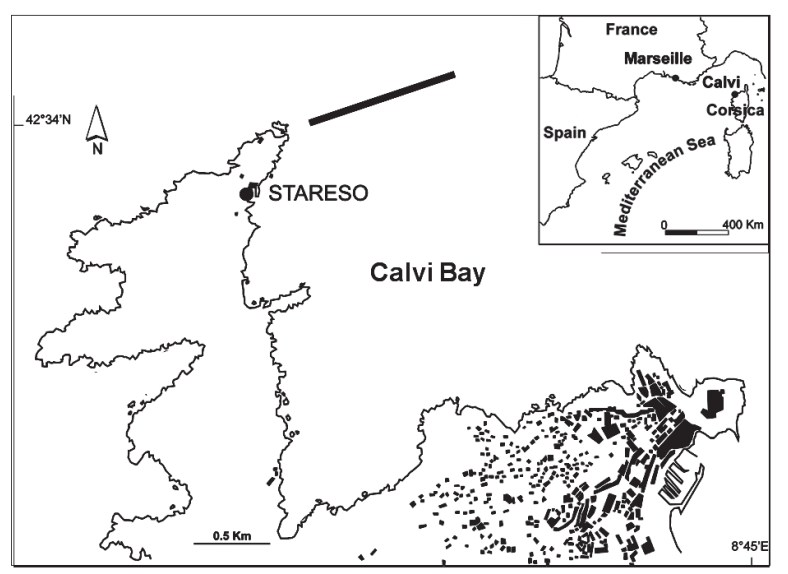

Fig. 1 - Map of Calvi Bay showing the STARESO research station and the sampling transect (solid black line) (modified from Vermeulen et al., 2011).
2011 and 10th July 2012. The sampling site, located near the STARESO oceanographic station (Calvi Bay, NW Corsica; Fig. 1), is characterized by very low anthropogenic influence (GOBERT et al., 2009). Neustonic and planktonic samples were collected with WP2 nets $(200 \mu \mathrm{m}$ mesh). The frame of the neuston net was rectangular $(0.60 \mathrm{~m} \mathrm{x} 0.25 \mathrm{~m})$ and the trawl sampled the top $20 \mathrm{~cm}$ of the water column. The frame of the plankton net was circular (diameter of $0.60 \mathrm{~m}$ ) and the trawl sampled at a depth of $5 \mathrm{~m}$. Nets were towed following a trajectory fixed by two points $\left(42^{\circ} 35^{\prime} 7.80^{\prime} \mathrm{N} 8^{\circ} 43^{\prime} 46.37^{\prime \prime} \mathrm{E}\right.$ and $42^{\circ} 35^{\prime} 5.09^{\prime \prime} \mathrm{N} 8^{\circ} 43^{\prime} 44.39^{\prime}$ 'E; Fig. 1) for 20 minutes between 7.00 AM and 8.00 AM, at a speed of $2 \mathrm{~km} / \mathrm{h}$. After collection, samples were concentrated to a volume of $0.2 \mathrm{~L}$ and fixed in $2.5 \%$ formalin.

A short period of ten days (from 30th August to 8 th September 2011) was chosen to evaluate the impact of wind stress on zooneustonic abundances. During this period, twelve neuston samples were collected at the same location (Fig. 1), using the methodology described above.

\section{Biovolume measurements and community structure assessment}

In order to rapidly and easily estimate the quantity of organisms, their biovolume was measured using a non-destructive method. Organisms were placed in a graduated cylinder, and after a 24 hour sedimentation period, it was possible to visually estimate the biovolume, i.e. the volume of the graduated cylinder occupied by all organisms. In two samples, we had to remove exceptional proliferations of Siphonophora (family of Hippopodiidae) and Velella that made precise biovolume estimation impossible. Neustonic organisms were examined and counted under a binocular microscope. For each neuston sample, occurring groups were listed. Important taxa (i.e. taxa supposedly characteristic of the neustonic environment and/or proportionally abundant in the samples) 
were counted. Particular attention was given to Pontellidae copepods. The main species identification criteria for this family (ROSE, 1933; TREgOUBOFF \& Rose, 1957) included the number of ocular lenses, the number of cephalic lateral hooks, the pincer type on males' last right appendages, and the presence and the shape of spikes on the last thoracic segment.

\section{Environmental parameters}

Wind speed and wind direction were measured near STARESO (42³4'43.32”N 8०43'8.36”'E; altitude $169 \mathrm{~m}$ ) using anAWS2700 weathersta-tion (Aanderaa Data Instruments, Bergen, Norway) equipped with a wind speed sensor 2740 and a wind direction sensor 3590. Measurements were done every 20 minutes, and data were averaged over the twelve hours before sampling. Wind speed is one of the most important parameters in the estimation of turbulence. Wind speed to the power of 3 can indeed be used as a turbulence proxy (STACEY \& POND, 1997). Precipitation data were obtained from Météo France. They were taken at Calvi airport $\left(42^{\circ} 31^{\prime} 23.88^{\prime \prime} \mathrm{N}\right.$ 8०47’30.01'”E; altitude $57 \mathrm{~m}$ ).

\section{Statistical analyses}

The relation between zooneuston abundance and environmental parameters was investigated using correlation analysis. Statistical analyses were conducted using Prism 5.03 (Graphpad Software, La Jolla, CA, U.S.A.). Significance threshold was fixed at $\alpha=0.05$.

\section{RESULTS}

\section{Neustonic biodiversity}

Twenty-one higher taxa belonging to 9 phyla were identified and counted (Table 1). Arthropoda was the most abundant group in the neuston. It was mainly represented by copepods, particularly the genera Clausocalanus and
Paracalanus (regrouped under the "Others" entry, Table 1). Pontellidae copepods were present in 16 of the 22 neuston samples. Contrastingly, they were rarely found in plankton ( 2 of the 22 samples), and only encountered in autumn. Most of the neustonic Pontellidae were immature individuals that could not be identified to the genus or species level. Besides those, 7 Pontellidae species belonging to 4 genera were observed during the sampling period. Pontella mediterranea (Table 1) was the most common adult Pontellidae in neuston samples, and the only one to be encountered in underlying plankton. Small copepods (Clausocalanus spp., Paracalanus spp., Oithona sp., Acartia sp.) were more abundant than large ones (Centropages sp., Temora sp., Pontellidae, Candacia sp.). Twentyeight genera of copepods were found, including four from the Pontellidae family.

Other major zooneustonic groups included Cladocera, Mollusca, Appendicularia, Chaetognatha, ichthyoplankton and Siphonophora, as well as Collozoum inerme (Table 1). Members of Foraminifera, Polychaeta, Decapoda (adults), Amphipoda or Ostracoda were more rare.

\section{Seasonal variations}

The mean neustonic biovolume was $5.1 \mathrm{ml} .(100$ $\left.\mathrm{m}^{2}\right)^{-1}$, varying between $0.8 \mathrm{ml} .\left(100 \mathrm{~m}^{2}\right)^{-1}$ and 14.0 ml. $\left(100 \mathrm{~m}^{2}\right)^{-1}$ throughout the studied year (Fig. 2). Neustonic biovolume did not seem to follow a clear seasonal pattern, and high values did not occur consistently: the highest value was found on 16th January 2012 (sample 10), the second highest on 24th April 2012 (sample 16) and the third on 8th May 2012 (sample 17).

No general seasonal pattern was found for total number of species, but some groupspecific trends were present (Table 1). The Acantharia Lithoptera spp. and the Pontellidae Pontellopsis regalis were the only organisms found in a single season. The acantharians were found in summer (beginning of September) and the copepods in autumn. By contrast, 
TABLE 1

Abundances and seasonal variations of dominant neustonic taxa. X: present, -: absent.

\begin{tabular}{|c|c|c|c|c|c|}
\hline Taxa & $\begin{array}{l}\text { Global mean } \\
\text { abundance } \\
\text { (ind. } 100^{-1} \mathrm{~m}^{-2} \text { ) }\end{array}$ & Summer & Autumn & Winter & Spring \\
\hline $\begin{array}{l}\text { Foraminifera } \\
\text { Globothalamea }\end{array}$ & - & $\mathrm{X}$ & $\mathrm{X}$ & - & $\mathrm{X}$ \\
\hline $\begin{array}{l}\text { Radiozoa } \\
\text { Acantharia }\end{array}$ & & & & & \\
\hline $\begin{array}{l}\text { Lithoptera spp. } \\
\text { Amoebozoa }\end{array}$ & 1.40 & $\mathrm{X}$ & - & - & - \\
\hline $\begin{array}{c}\text { Lobosa incertae sedis } \\
\text { Collozoum inerme } \\
\text { Cnidaria }\end{array}$ & 30.4 & $\mathrm{X}$ & $\mathrm{X}$ & $\mathrm{X}$ & $\mathrm{X}$ \\
\hline $\begin{array}{l}\text { Hydrozoa } \\
\text { Siphonophora } \\
\text { Annelida }\end{array}$ & 24.6 & $\mathrm{X}$ & $\mathrm{X}$ & $\mathrm{X}$ & $\mathrm{X}$ \\
\hline $\begin{array}{l}\text { Polychaeta } \\
\text { Mollusca } \\
\text { Gastronoda }\end{array}$ & - & - & $\mathrm{X}$ & $\mathrm{X}$ & $\mathrm{X}$ \\
\hline $\begin{array}{l}\text { Creseis sp. } \\
\text { Chaetognatha }\end{array}$ & 342 & $\mathrm{X}$ & $\mathrm{X}$ & $\mathrm{X}$ & - \\
\hline $\begin{array}{l}\text { Sagittoidae } \\
\text { Arthropoda }\end{array}$ & 29.2 & $\mathrm{X}$ & $\mathrm{X}$ & $X$ & $\mathrm{X}$ \\
\hline $\begin{array}{l}\text { Maxillopoda } \\
\text { Copepoda } \\
\text { Calanoida } \\
\text { Pontellidae }\end{array}$ & & & & & \\
\hline Immature Pontellidae & 96 & $\mathrm{X}$ & $\mathrm{X}$ & - & - \\
\hline Anomalocera patersoni & 0.58 & - & - & $\mathrm{X}$ & $\mathrm{X}$ \\
\hline Labidocera brunescens & 30.8 & $\mathrm{X}$ & $\mathrm{X}$ & $\mathrm{X}$ & $\mathrm{X}$ \\
\hline Labidocera wollastoni & 0.08 & $\mathrm{X}$ & $\mathrm{X}$ & - & - \\
\hline Pontella lobiancoi & 0.07 & - & - & - & - \\
\hline Pontella mediterranea & 23.6 & $\mathrm{X}$ & $\mathrm{X}$ & - & - \\
\hline Pontellopsis regalis & 0.02 & - & $\mathrm{X}$ & - & - \\
\hline $\begin{array}{l}\text { Pontellopsis villosa } \\
\text { Other families }\end{array}$ & 0.10 & $\mathrm{X}$ & $\mathrm{X}$ & - & - \\
\hline Acartia sp. & 154 & $\mathrm{X}$ & $\mathrm{X}$ & $\mathrm{X}$ & $\mathrm{X}$ \\
\hline Candacia sp. & 1.70 & - & $\mathrm{X}$ & $\mathrm{X}$ & - \\
\hline Centropages spp. & 163 & $\mathrm{X}$ & $\mathrm{X}$ & $\mathrm{X}$ & $\mathrm{X}$ \\
\hline Oithona sp. & 314 & $\mathrm{X}$ & $\mathrm{X}$ & $\mathrm{X}$ & $\mathrm{X}$ \\
\hline Temora sp. & 162 & $\mathrm{X}$ & $\mathrm{X}$ & - & - \\
\hline Others & 9375 & $\mathrm{X}$ & $\mathrm{X}$ & $\mathrm{X}$ & $\mathrm{X}$ \\
\hline Cladocera & 1024 & $\mathrm{X}$ & $\mathrm{X}$ & - & $\mathrm{X}$ \\
\hline $\begin{array}{l}\text { Malacostraca } \\
\text { Isopoda }\end{array}$ & 1.35 & - & $\mathrm{X}$ & $\mathrm{X}$ & $X$ \\
\hline Chordata & & & & & \\
\hline $\begin{array}{l}\text { Appendicularia } \\
\text { Salpa spp. } \\
\text { Actinopterygii }\end{array}$ & 180 & $\mathrm{X}$ & $\mathrm{X}$ & $\mathrm{X}$ & $\mathrm{X}$ \\
\hline Eggs & 25.6 & $\mathrm{X}$ & $\mathrm{X}$ & $\mathrm{X}$ & $\mathrm{X}$ \\
\hline Larvae & 2.31 & $\mathrm{X}$ & $\mathrm{X}$ & $\mathrm{X}$ & $\mathrm{X}$ \\
\hline
\end{tabular}




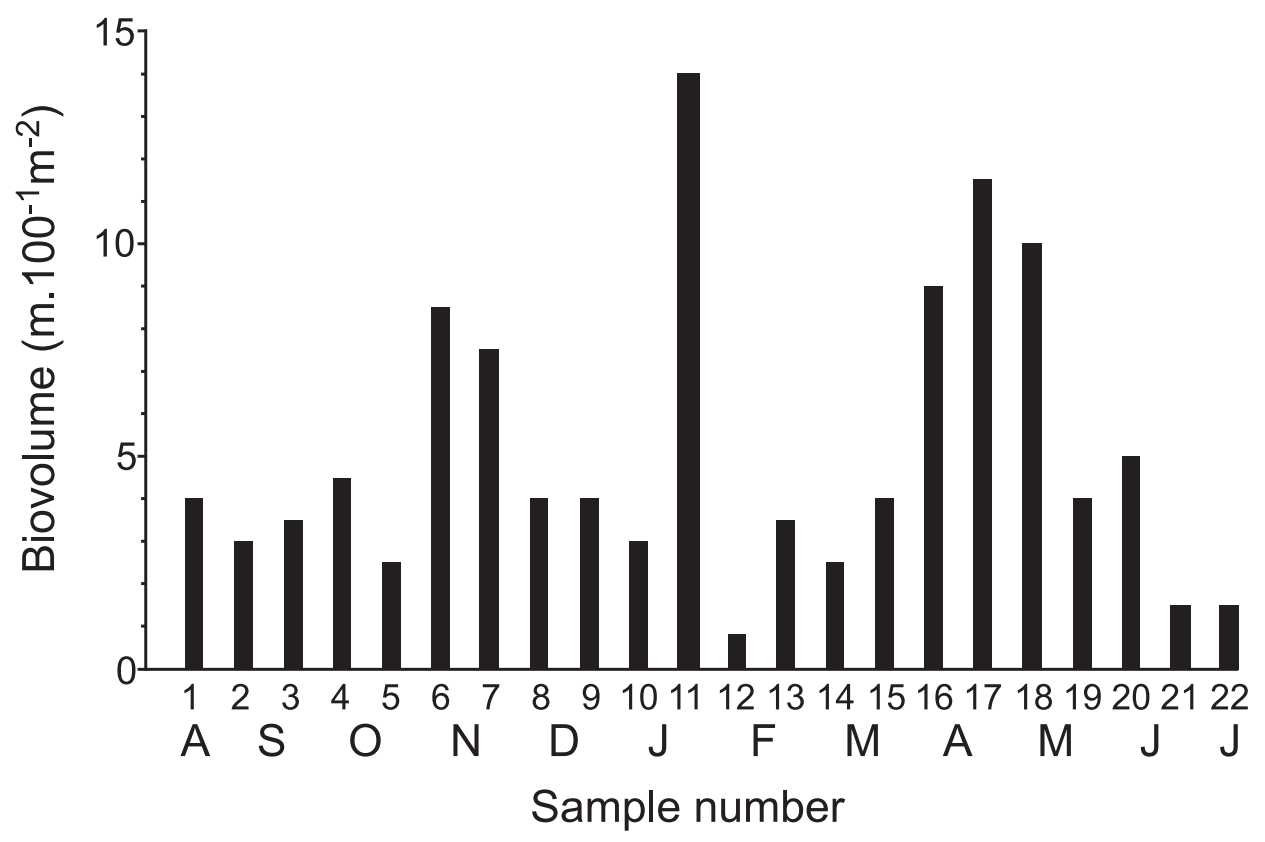

Fig. 2 - Neustonic biovolume variations from August 2011 to July 2012.

several groups were present throughout the whole sampling period: Collozoum inerme, Paracalanus spp., Clausocalanus spp., Oithona sp., Acartia sp., Centropages spp., Appendicularia, Chaetognatha, Siphonophora, and ichthyoplankton. Most Pontellidae species were found in summer or in autumn, with the exception of Anomalocera patersoni which was found in spring and winter. The maximal Pontellidae abundance (1602 ind. $\left.100^{-1} \mathrm{~m}^{-2}\right)$ occurred on 4th October 2011 (Fig. 3). Molluscan Creseis sp. and copepods Temora sp. were present in autumn and absent in spring. Cladocerans were abundant in September 2011, June and July 2012. Their numbers strongly decreased in October 2011 and they progressively disappeared from November 2011 to April 2012.

\section{Relationship with wind stress and turbulence}

During the ten days of measurement, wind directions associated with neuston sampling events fluctuated between $71^{\circ}$ (ENE) and 260 (W) and wind speed ranged between $0.6 \mathrm{~m} / \mathrm{s}$ and $14.8 \mathrm{~m} / \mathrm{s}$.
Although a non-significant negative trend seemed to be present for Pontellidae (data not shown), no correlation was found between turbulence and abundance of any of the neustonic taxa.

Mean wind direction, however, influenced the abundance of Pontellidae (Fig. 4, $\mathrm{r}^{2}=0.7848, \mathrm{p}=$ 0.0001) and Chaetognatha (Fig. 4, $\mathrm{r}^{2}=0.4969, \mathrm{p}$ $=0.0105$ ). Pontellidae were more abundant when wind blew from the north-east than when it blew from the south-west. Inversely, Chaetognatha were less abundant when wind blew from the east (Fig. 4). No correlation between abundance and wind direction was found for any of the other counted taxa.

\section{DISCUSSION}

The neustonic environment contains a diverse assemblage of organisms. Crustacea, and mostly copepods, were the most important group in terms of biodiversity and abundance Other major groups included Mollusca, Appendicularia, early life stages of fish, Siphonophora and Amoebozoa. Other species of Cnidaria, Acantharia and 


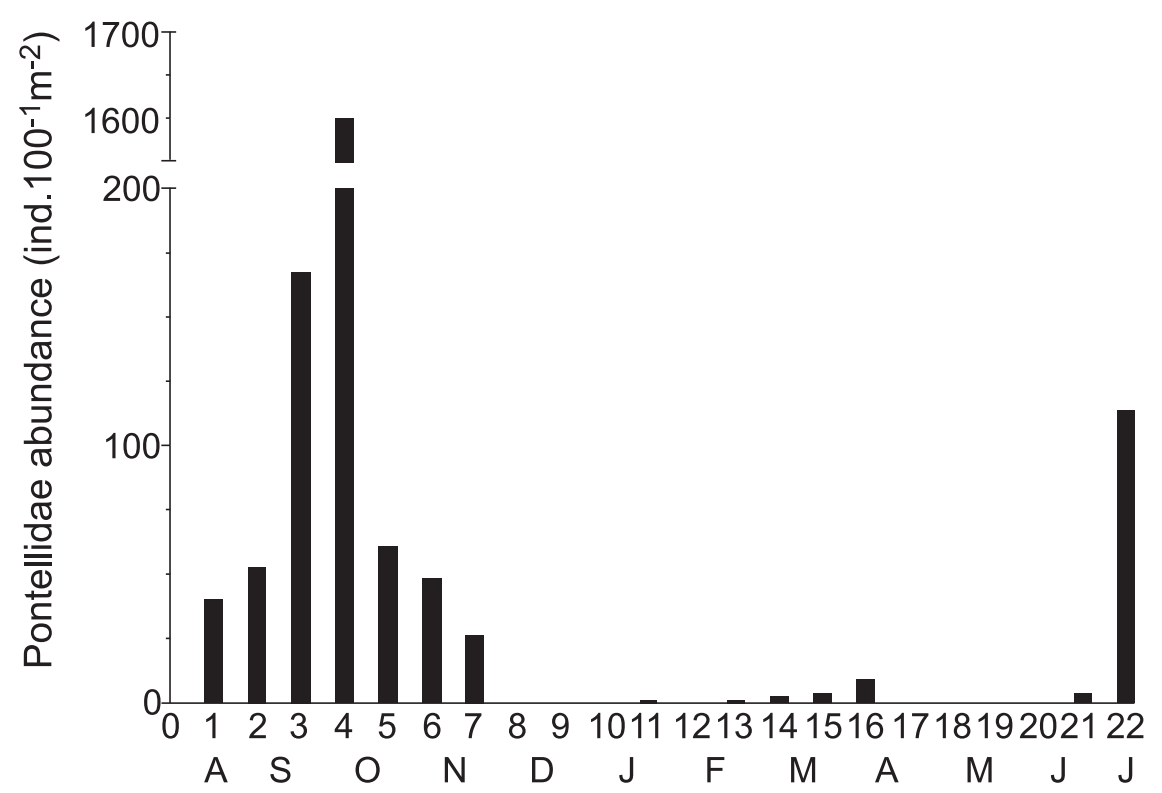

Fig. 3 - Pontellidae abundance variations from August 2011 to July 2012.

Foraminifera were less abundant, but regularly observed. Our results are comparable with another study from the NW Mediterranean (LICANDRO \& ICARDI, 2009). Neuston biodiversity highlights the ecological importance of this zone.

Pontellidae copepods are known to be specific to the neuston. In Calvi Bay, they were accordingly much more frequently observed in neuston than in underlying plankton. In the
Red Sea, they seem to be absent from samples taken "just beneath the surface" (i.e. a bit deeper than our neuston samples) of the sea (KHALIL et al., 1997), supporting the fact that Pontellidae copepods mostly live in the first centimeters of the water column. Species of Pontellidae have surface attachment structures (SAS), formed by several patches of setae on the dorsoanterior surface of the cephalosome and the second thoracic segment (IANORA et al., 1992).

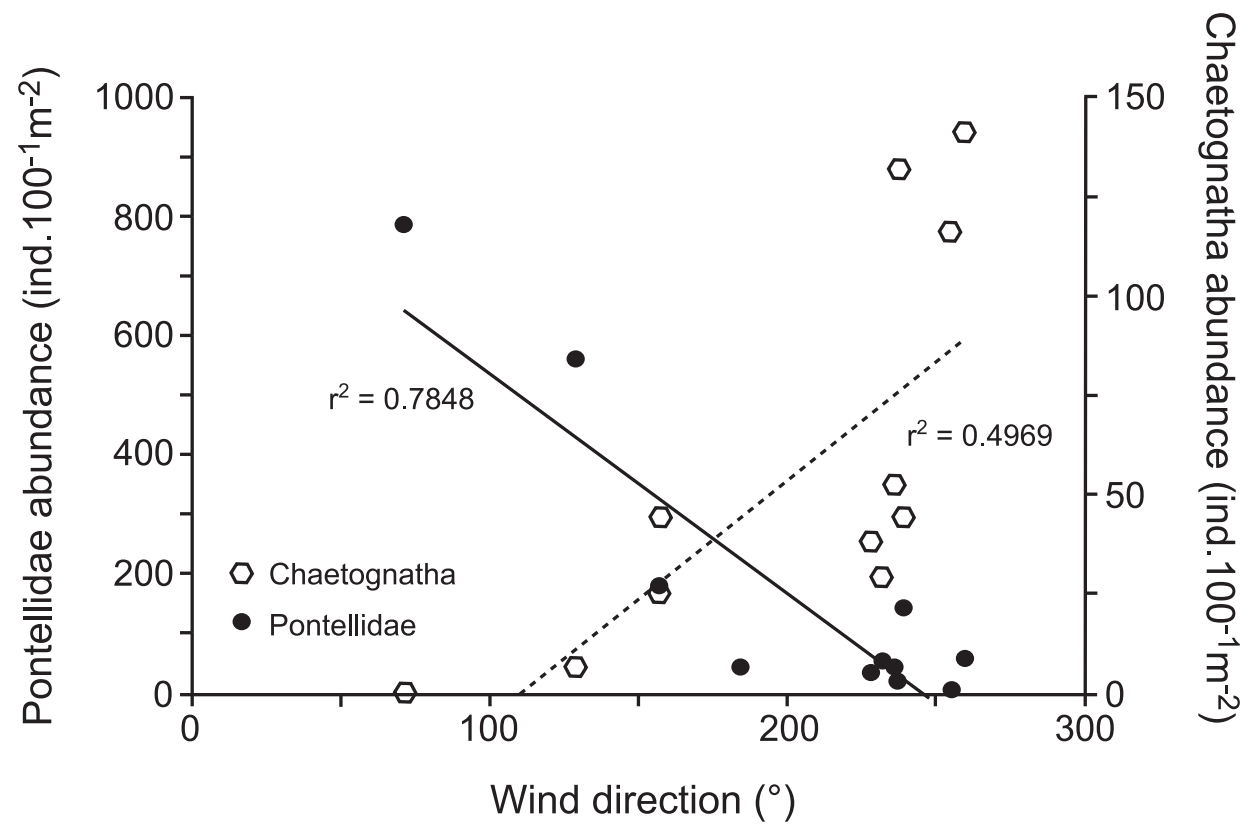

Fig. 4 - Correlations between Pontellidae and Chaetognatha abundances and wind direction. 
These SAS are thought to be an energy-saving way to adhere to the surface film, and may therefore represent a morphological adaptation to neustonic lifestyle. SAS are not present in all species of Pontellidae (PENNELL, 1973). It appears that only species of Pontellidae with bright colors possess an SAS. This pigmentation is thought to play a protective role against the ultraviolet rays to which Pontellidae with SAS are more exposed.

A negative linear correlation between abundance of Pontellidae and wind direction was highlighted. When wind blows from the northeast, abundance of Pontellidae is high, while abundance is low when wind blows from the south-west. The offshore opening of Calvi Bay is towards the northeast (Fig. 1). A northeasterly wind therefore causes offshore surface water to enter the bay. High Pontellidae abundance in this advected water could therefore explain the observed correlation.

As explained by HOLDWAY \& MADDOCK (1983), abundance and diversity in the neuston vary with the day/night cycle. In their study, some taxa were more abundant during the night (e.g. Amphipoda and Ostracoda) or during the day (e.g. Appendicularia). Several taxa were more numerous at dusk or dawn (e.g. Lucifer spp. and Cnidaria except Siphonophora). We are aware of this influence on diversity and abundance. Nevertheless, for practical reasons (boat and staff availability), samples have been collected at the same hour each day. Further studies based on samples taken during multiple times of the day are needed to improve our knowledge of dynamics of Mediterranean communities.

Chaetognatha abundances, on the other hand, were inversely impacted by wind direction. These two correlations should be confirmed by concomitant sampling in the bay and offshore.

Although our study is a first step towards a better knowledge of neuston community structure in the Mediterranean Sea, information about this particular layer of the sea remains scarce. It would be interesting to know what drives dominance of certain taxa in the neuston, and what are their ecological impacts on other compartments of the pelagic ecosystem. The surface layer is indeed a feeding location for fish, as well as an accumulation zone of pollutants. In the context of increasing human population, and consequently of increasing pollution and fishing activities, neuston assemblages could undergo drastic changes. Whether or not these changes could have adverse effects on the underlying parts of the water column is a question that will only be answered through further understanding of neuston ecology.

\section{ACKNOWLEDGEMENTS}

This work was supported by the F.R.S.-FNRS (Fonds de la Recherche Scientifique), the FRIA (Fonds pour la Recherche dans l'Industrie et l'Agriculture) and the IFREMER (Institut Français de Recherche pour l'Exploitation de la Mer). We thank the crew of STARESO for sampling and logistical support, and J. Schnitzler (Laboratory of Oceanology, ULg) for his language advice and corrections. This paper is MARE publication nr. 281.

\section{REFERENCES}

CARdinale M, CASINI M, ARRHENIUS F, HÅKANSSON N (2003). Diel spatial distribution and feeding activity of herring (Clupea harengus) and sprat (Sprattus sprattus) in the Baltic Sea. Aquatic Living Resources 16:283-92.

Collignon A, HecQ JH, Glagani F, Voisin P, COLlard F \& GOFFART A (2012). Neustonic microplastic and zooplankton in the North Western Mediterranean Sea. Marine Pollution Bulletin, 64:861-864.

Collignon A, HecQ JH, Galgani F, Collard F, GOFFART A (2014). Annual variation in neustonic micro- and meso-plastic particles and zooplankton in the Bay of Calvi (Mediterranean-Corsica). Marine Pollution Bulletin 79:293-98.

FRANKLIN MP, MCDONALD IR, BOURNE DG, OWENS NJP, UPSTILL-GODDARD RC \& MURRELL JC 
(2005). Bacterial diversity in the bacterioneuston (sea surface microlayer): The bacterioneuston through the looking glass. Environmental Microbiology, 7:723-736.

Garcia-Flor N, Alzaga R, Ortiz L, Bayona JM \& Albaiges J (2008). Determination of organochlorine compounds in neuston from the Mediterranean. Environmental Technology, 29:1275-1283.

Gobert S, SARTORETto S, Rico-Raimondino V, ANDral B, Chery A, LeJeune P, BoIsSERy P (2009). Assessment of the ecological status of Mediterranean French coastal waters as required by the Water Framework Directive using the Posidonia oceanica Rapid Easy Index: PREI. Marine Pollution Bulletin, 58:1727-1733.

GREGORY MR (2009). Environmental implications of plastic debris in marine settings-entanglement, ingestion, smothering, hangers-on, hitch-hiking and alien invasions. Philosophical Transactions of the Royal Society B-Biological Sciences, 364:2013-2025.

HANEY JF (1988). Diel patterns of zooplankton behavior. Bulletin of Marine Science, 43:583-603.

HARADA E, NISHINO M \& NARITA T (1985). A partite plankton sampler and summer vertical structure of zooplankton revealed using it in shallow brackish waters, Lake Shinji-ko and Lake Naka-umi. Physiology \& Ecology Japan, 22:37-57.

HARDY JT \& APTS CW (1984). The sea-surface microlayer: phytoneuston productivity and effects of atmospheric particulate matter. Marine Biology, 82:293-300.

HERMAN AW (1984). Vertical copepod aggregations and interactions with chlorophyll and production on the Peru shelf. Continental Shelf Research, 3:131-146.

HoldWAY P, MADDOCK L (1983). A comparative survey of neuston: geographical and temporal distribution patterns. Marine Biology, 76:263-70.

IANORA A, Miralto A, VANucCi S (1992). The surface attachment structure: a unique type of integumental formation in neustonic copepods. Marine Biology, 113:401-407.

KHALIL MT \& ABD EL-RAHMAN NS (1997). Abundance and diversity of surface zooplankton in the Gulf of Aqaba, Red Sea, Egypt. Journal of Plankton Research, 19:927-936.

LAIST DW (1997). Impacts of marine debris: entanglement of marine life in marine debris including a comprehensive list of species with entanglement and ingestion records. In: COE JM \& Rogers DB (eds), Marine debris, sources, impacts, and solutions, New York: SpringerVerlag: 99-139.

LICANDRO P \& ICARDI P (2009). Basin scale distribution of zooplankton in the Ligurian Sea (north-western Mediterranean) in late autumn. Hydrobiologia 617:17-40.

LYALYUK NM\& LIPNITSKAYA GP(2003). Distribution of unicellular algae at the surface of the pelagic zone of the sea of Azov. Hydrobiological Journal, 39:59-64.

Mato Y, Isobe T, TAKada H, Kanehiro H, Ohtake C \& KAMINUMA T (2001). Plastic resin pellets as a transport medium for toxic chemicals in the marine environment. Environmental Science \& Technology, 35:318-324.

NAUMANN E (1917). Beiträge zur kenntnis des teichnanoplanktons. II. Über das neuston des süßwasser. Biologische Zentralblatt, 37:98-106.

OLIVAR MP \& SABATES A(1997). Vertical distribution of fish larvae in the north-west Mediterranean Sea in spring. Marine Biology, 129:289-300.

PENNELl WM 1973. Studies on a member of the pleuston, Anomalocera opalus n.s. (Crustacea, Copepoda) in the Gulf of St. Lawrence. Ph.D. thesis, Marine Sciences Centre, McGill University, Montreal.

Pusineri C, Vasseur Y, Hassani S, Meynier L, SpITZ J, RidouX V (2005). Food and feeding ecology of juvenile albacore, Thunnus alalunga, off the Bay of Biscay: A case study. ICES Journal of Marine Science 62:116-22.

Rose M (1933). Faune de France : Copépodes pélagiques. Kraus, Paris, 374 pp.

RYAN PG, MOORE CJ, VAN FRANEKER JA \& MOLONEY CL (2009). Monitoring the abundance of plastic debris in the marine environment. Philosophical Transactions of the Royal Society B-Biological Sciences, 364:1999-2012.

SIEBURTH JM (1983). Microbiological and organicchemical processes in the surface and mixed layers. In: LISS PS \& SLINN WGN (eds), AirSea Exchange of Gases and Particles, Reidel Publishers Co: Hingham, MA:121-172.

STACEY MW \& POND S (1997). On the MellorYamada Turbulence Closure Scheme: The Surface Boundary Condition for q2. Journal of Physical Oceanography, 27:2081-2086. 
Tiselius P (1992). Behavior of Acartia tonsa in patchy food environments. Limnology \& Oceanography, 37:1640-1651.

Tregouboff G \& Rose M (1957). Manuel de planctonologie méditerranéenne. Centre national de la recherche scientifique, Paris, $587 \mathrm{pp}$.

Vermeulen S, Sturaro N, Gobert S, BOUQUEGNEAU JM, LEPOINT G. (2011). Potential early indicators of anthropogenically derived nutrients: A multiscale stable isotope analysis. Marine Ecology Progress Series 422:9-22.

ZAITSEV YP(1971). Marineneustonology. Jerusalem: Israel Program for Scientific Translations (I.P.S.T.).

Received: June 6th, 2014

Accepted: December 1st, 2014

Branch editor: Marleen de Troch 